\begin{tabular}{|c|c|c|c|c|c|c|c|c|c|c|c|c|c|}
\hline Weight (kg) & 7 & & 8 & & & 9 & & & 10.5 & & & $11 \cdot 2$ & 11.5 \\
\hline Height $(\mathrm{cm})$ & 66 & & $6 s$ & & & 72 & & & 77 & & & 82 & 85 \\
\hline $\operatorname{MCV}(f \mid)$ & 92 & & 92 & & & 92 & & & 92 & & & 92 & 92 \\
\hline $\begin{array}{l}\operatorname{CD4} \\
\left(0.1 \times 10^{9} / 1\right)\end{array}$ & 450 & 388 & & & & 650 & & 500 & & & & 190 & 192 \\
\hline $\begin{array}{l}\text { P24 antigen } \\
\text { (pg/ml) }\end{array}$ & 356 & 386 & & 0 & 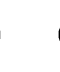 & 0 & & 0 & 0 & & 0 & 0 & \\
\hline $\begin{array}{l}\text { Platelets } \\
\left(\times 10^{9} / 1\right)\end{array}$ & $\begin{array}{lll}10 & 10 & 280\end{array}$ & 10 & 390 & 480 & 450 & 380 & 10 & 290 & 10 & 350 & 450 & 350 & 350 \\
\hline
\end{tabular}

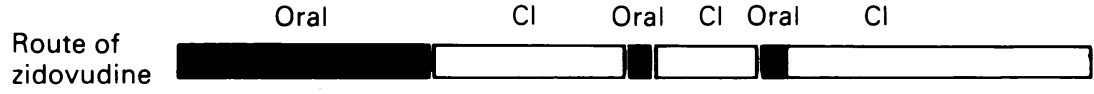

\title{
Age
}

(months)

12

19

22

25

33

36

Patient's data covering a period of 20 months, starting at 12 months of age when thrombocytopenia developed; $C I=$ continuous infusion, $M C V=$ mean corpuscular volume.

anaemia. On two occasions (at 22 and 25 months of age) the intravenous route was transiently switched to oral treatment at a daily dose of $600 \mathrm{mg} / \mathrm{m}^{2}(24 \mathrm{mg} / \mathrm{kg})$ given in four or six divided doses. Each time a symptomatic relapse occurred and was corrected when the intravenous route was resumed. Plasma concentrations of zidovudine were measured by high performance liquid chromatography. ${ }^{2} \mathrm{~A}$ $150 \mathrm{mg} / \mathrm{m}^{2} / 6$ hours $(24 \mathrm{mg} / \mathrm{kg} /$ day $)$ given orally, the peak plasma concentration one hour after oral dosing was $800 \mathrm{ng} / \mathrm{ml}$ and the trough level was undetectable (limit of detection: $12.5 \mathrm{ng} /$ $\mathrm{ml}$ ); these levels were similar to those determined in our other HIV positive children, excluding a specific defect of zidovudine absorption in our patient. Steady state concentration was $534 \mathrm{ng} / \mathrm{ml}$ during continuous infusion.

CHERIF RAHIMY

EVELYNE JACOZ-AIGRAIN * ANNE BROYARD FRANÇOISE BRUN-VÉZINET * ETIENNE VILMER Departments of Haematology-Immunology and Clinical Pharmacology Hôpital Robert Debré, 75019 Paris, France

1 Pizzo PA, Eddy J, Falloon J, et al. Effect of continuous intravenous infusion of zidovudine (AZT) in children with symptomatic HIV infection. N Engl f Med 1988; 319: 889-96.

2 Good SS, Reynolds DJ, de Miranda P. Simultaneous quantification of $\mathrm{ZDV}$ and its glucuronide in serum by high performance liquid chromatography. $\mathcal{F}$ Chromatogr 1988; 431: 123 33 .

\section{Reporting of vaccine associated mumps meningitis}

EDITOR, - Vaccine associated mumps meningitis was one of the conditions reportable to the British Paediatric Surveillance Unit (BPSU) between February 1990 and January 1992 During this two year period, 15 confirmed cases were reported.' Eight reports were in children aged 12-24 months resident in England and Wales. Based on the BPSU study the estimated risk of vaccine associated mumps meningitis in this age group was 1.5 per 100000 vaccinations given. However when the BPSU data were supplemented by laboratory reports, a much higher rate of approximately 10 per 100000 vaccinations was observed (Dr E Miller, personal communication). This higher rate is consistent with observations in other countries. $^{2}$
The low rate derived from BPSU reports may be due to the fact that paediatricians did not link the illness (which was usually mild) to measles, mumps, rubella vaccination, which had been given up to 28 days previously. This could be avoided by taking a full immunisation history (including dates) on all children at the time of admission. Particular attention should be paid to vaccinations in the previous month.

\section{NORMAN BEGG \\ PHLS Communicable Diseas Surveillance Centre, 61 Colindale Avenue, London $N W^{\prime} 95 E Q$}

1 British Paediatric Surveillance Unit. Sixth annua report. London: BPSU, 1991.

2 Sugiura A, Yamada A. Aseptic meningitis as complication of mumps vacination. Pediatr Infect Dis ₹ 1991; 10: 209-13.

Haemorrhagic shock encephalopathy or near miss sudden infant death syndrome?

EDITOR,-Drs Bacon and Hall suggest that haemorrhagic shock encephalopathy syndrome (HSES) is probably a secondary phenomenon after a severe initial insult.' We hypothesise that this syndrome may represent the result of acute onset, severe hypoxaemia as may occur in infants who suffer apparent life threatening events (ALTE). ${ }^{2}$ Many of the features of HSES are similar to those that occur in infants who have suffered ALTE or sudden infant death syndrome (SIDS): median age of 15 weeks, peak onset period at night, slight excess in winter months, mild prodromal illness, found hot and sweaty, and with postmortem pulmonary congestion.

Previous reports on changes after severe 'near miss' SIDS have also shown the presence of metabolic acidosis, cardiovascular instability, acute renal failure, ischaemic colitis and acute neurological dysfunction. ${ }^{3}$ Some of these infants also showed mild hepatocellular dysfunction and hyponatraemia.

It may be appropriate for infants who have recovered from HSES to be screened for abnormalities in oxygenation. However, as with SIDS, the dilemma is to identify patients at risk of this life threatening illness before symptoms develop.

MARTIN SAMUELS DAVID P SOUTHALL Academic Department of Paediatrics, University of Keele, North Staffordshire Hospital Centre Stoke on Trent ST4 6QG
1 Bacon CJ, Hall SM. Haemorrhagic shock encephalopathy syndrome in the British Isles. encephalopathy syndrome in the
Arch Dis Child 1992; 67: 985-93.

2 Samuels MP, Poets CF Noyes JP, Hartmann

H, Hewertson J, Southall DP. Diagnosis and management after life threatening events in infants and young children who received cardiopulmonary resuscitation. BMF 1993; 306: 489-92.

3 Constantinou JEC, Gillis J, Ouvrier RA, Rahilly PM. Hypoxic ischaemic encephalopathy after near miss sudden infant death syndrome. Arch Dis Child 1989; 64: 703-8.

\section{Treatment of refractory ulcerative} oesophagitis with omeprazole

EDITOR,-We read the paper of Dalzell et al with interest. ' They reported a complete resolution of ulcerative oesophagitis refractory to $\mathrm{H}_{2}$ blockers by omeprazole in a 7 year old boy.

We recently saw a 4 month old boy who was diagnosed endoscopically to have an ulcerative oesophagitis at the age of 2 months. A two month course of cisapride, cimetidine, and a mucosal protective agent (alginate antacid), together with thickening of the feeds and positioning initially improved his symptoms of crying when drinking milk. While still taking this treatment, however, excessive crying during and after milk feeding reoccurred. Urine analysis was normal. A semielemental diet had already been introduced without obvious benefit. Endoscopy revealed a marked distal oesophagitis. Omeprazole at $3.5 \mathrm{mg}(0.5$ $\mathrm{mg} / \mathrm{kg}$ ) once a day was given for a period of six weeks. During the first 48 hours of this treatment, the clinical symptoms disappeared spectacularly. Endoscopy five weeks later did not reveal any signs of oesophagitis.

In adults, omeprazole, a substituted benzimidazole with strong, prolonged 24 hour inhibition of gastric acid secretion by blocking $\mathrm{H}^{+} / \mathrm{K}^{+}$-ATPase in parietal cells, is very effective in treating severe oesophagitis refractory to treatment with $\mathrm{H}_{2}$ receptor antagonists. Rare side effects such as myopathy, epidermal necrosis, and endocrine adverse effects have been described. ${ }^{2+}$ In infants and children, however, there is lack of experience and cautious use is warranted. Our report is to our knowledge the first to describe a beneficial effect of omeprazole on refractory oesophagitis in a young infant. Like Dalzell et al we suggest that omeprazole should be considered as an alternative treatment for ulcerative oesophagitis resistant to traditional treatment.

PHILIPPE ALLIËT
MARC RAES
PHILIPPE GILLIS
MIEKE CALLEWAERT
ANDRÉ ZIMMERMANN
Virga fesse Hospital,
Department of Paediatrics,
Stadsomvaart 11,
$B-3500$ Hassel,
Belgium

1 Dalzell AM, Searle JW, Patrick MK. Treat ment of refractory ulcerative ment of refractory ulcerative oesophagitis
omeprazole. Arch Dis Child 1992;67: 641-2.

2 Garotte FJ, Lacambra C, Del Ser T, et al. Subacute myopathy during omeprazole therapy. Lancet 1992; 340: 672.

3 Cox NH. Acute disseminated epidermal necrosis due to omeprazole. Lancet 1992; 340: 857

4 Lindquist M, Edwards IR. Endocrine adverse effects of omeprazole. $B M \mathcal{F}$ 1992; 305: 451-2.

\section{Recurrent parotitis}

EDITOR, - We were interested to read that the cause of recurrent parotitis in children 'has of yet not been satisfactorily explained'.' 